\title{
A SENSITIVE PENETROMETER FOR MEASURING SOIL PENETRATION RESISTANCE
}

\author{
Agric. Eng. Res. Inst., ARC, Egypt
}

YUSUF Y. R.R.

(Manuscript received 21 March 2018)

\begin{abstract}
$\mathrm{S}$ oil compaction is one of the main negative factors that limits plant growth and crop yield. Soil mechanical resistance can be used as an indicator of soil compaction. This study is focused on the design of a penetrometer, which can make instantaneous soil resistance measurements in the soil without human faults. The penetrometer consists of a load cell, an electric motor, an internal helical screw rod, a probe, bubble balances, a graduated scale, a digital screen, a battery and additional attachments. Laboratory calibration and tests were carried out. In the field, according to soil depth of 0-15, 15-30, 30-45 and 45-60 $\mathrm{cm}$ soil penetration resistance was measured in the field under different conditions of soil moisture content and soil bulk density. General results showed that, in un-compacted soil, range of soil penetration resistance values were 0.306 and $0.991 \mathrm{MPa}$ whereas, in compacted soil, the range of penetration resistance were 0.891 and $2.371 \mathrm{MPa}$, respectively at $30-45 \mathrm{~cm}$ soil depth under different conditions of moisture content and bulk density. In conclusion, the experimental results showed that the designed system works quite well in the field and the vertical static penetrometer is a practical instrument for providing direct soil penetration resistance measurements.

Keywords: vertical penetrometers; cone index; soil penetration resistance
\end{abstract}

\section{INTRODUCTION}

Penetrometers are divided into two main types named horizontal and vertical penetrometers. The first type, horizontal one, offers more data on the field, so the high volume of data at hand provides more opportunity to make active, effective and productive evaluations about the field type. But the most crucial factors during the data collection is speed progress which must to be kept as constant as possible. This couldn't be achieved in the field and consequently gives a hesitative data. The other type is the vertical penetrometers which give an accurate data with providing a wide range of data according to more shifting in the field. The tractors, tillage tools and the machine systems which are used in the agricultural production can cause field traffic. Especially today's machines such as powerful tractors, combine harvesters etc. which are becoming heavier because of their additional attached equipment, have become a reason for high level of soil compaction observed in agricultural fields, (Tekin et al. 2008). 
Penetrometers can also be divided into two groups, depending on the penetration method: (a) dynamic or impact, where the penetrometer cone is pushed into the soil by successive hammer blows. Penetration resistance is calculated as the work by the soil needed to stop cone movement divided by the penetration distance. The work by the soil is defined as the kinetic energy of the hammer when it impacts the strike plate. The standard drop height and hammer mass ensure measurements are consistent between operators (Jeffrey and Tim, 2002) and (b) static, where the cone is pushed into the soil at a speed as constant as possible, by manual action or hydraulic or electro-hydraulic mechanisms (constant speed). For example, coupled to tractor hydraulic systems or to utility vehicles with motors adapted for field use (Rooney \& Lowery, 2000). However, the drawback of these systems is the damaging effects of vehicle traffic on the experimental areas.

Campbell \& O' Sullivan (1991) mentioned that the major soil factors affecting soil penetration resistance are soil moisture content, bulk density, soil type, and soil structure. Important components of soil type affecting soil penetration resistance include texture, mineralogy, chemical properties, and organic matter. Both soil structure and type are difficult to measure for predictive purposes. If, however, only one soil type is considered and soil structure does not vary, the major factors affecting soil penetration resistance will be soil moisture and bulk density. They also reported that relationships between soil penetration resistance (PR), bulk density (BD), and soil moisture (MC) can often be described either by additive models of the form:

$$
P R=a+b(M C)+c(B D)+d(B D \times M C)
$$

or, where relationships are derived from a wider range of bulk density and soil moisture values, by multiplicative models of the form:

$$
\mathrm{PR}=\mathrm{a}(\mathrm{MC})^{\mathrm{b}}(\mathrm{BD})^{\mathrm{C}}
$$

where $a, b$, and $c$ are empirical constants.

Manually operated static penetrometers suffer from several limitations. They are relatively expensive, must be moved through the soil at a constant velocity, must be recalibrated on a regular basis in order to generate consistent, repeatable measurements, and are designed for a relatively limited range of soil resistance. Manually operated penetrometers often yield variable results when used by the same operator and especially when used by different operators because of differences in the rate of insertion. Correct interpretation of static penetrometer data also requires insertion into the soil at a constant velocity (i.e., probe acceleration nearly to zero), so that the soil resistive force can be assumed equal to the total force applied to the penetrometer. If penetrometer velocity changes, then the soil resistive force will be 
either more (negative probe acceleration) or less (positive probe acceleration) than measured by the operator. Constant probe velocity is difficult to maintain in manually operated penetrometers Mehmet et al. (2010). During compaction, soil particles get closer each other and a diminishing of the entrapped air is observed. As a result; an increase is seen for soil bulk density and soil penetration resistance (Raper, 2005 and Carrara et al. 2007). Soil compaction has also a negative effect on the physical, chemical and biological properties of the soil. This negative effect limits roots growth and the plants cannot complete their growth properly. Hence, less yield and economic losses are obtained. In addition to this, the machines, which are operating on the compacted soil need extra energy (Adamchuk et al., 2003). Therefore, the determination of the soil penetration resistance level is quite important for sustainable production, yield and conservation of the farmland. Soil penetration resistance (PR) is one of the most commonly used indicators of soil physical quality in agronomic evaluations (Beutler et al., 2001; Pedrotti et al., 2001). PR is also used as an indicator of the effect of soil management systems (Dexter et al., 2007; Ralisch et al., 2008; Veiga et al., 2009). It is determined by the use of penetrometers, which measure the resistance of the soil to penetration related to a standardized cone (ASAE, 1999), located at the end of a metal rod, which is inserted into the soil.

Mehmet et al. (2010) designed a penetrometer, which can make instantaneous soil resistance in the field for a soil depth of $40 \mathrm{~cm}$. As a result, soil resistance values of $0.2 \mathrm{MPa}$ and $3 \mathrm{MPa}$ were obtained as minimum and maximum values, respectively. A number of static designs are commercially available. Most consist of a rigid, cone-tipped rod attached to a pressure measuring device. The measuring device is usually a load cell or strain gauge coupled with an analog dial or pressure transducer for readout.

Ani and Mbajiorgu (2008) followed the recommendations in ASAE standards while designing a cone penetrometer. The dimensions of the cone selected were: enclosed angle of $30^{\circ}$, cone-base area of $323 \mathrm{~mm}^{2}$, and diameter of $20.27 \mathrm{~mm}$; mounted on a $15.88 \mathrm{~mm}$ diameter shaft.

João Carlos et al. (2010) identified the critical compaction depth, to test the functionality of a new, portable penetrometer developed from a spring dynamometer, and compare it to an electronic penetrometer traditionally used in compaction studies of agricultural soils. The critical soil resistance defined to establish critical compaction depth was equal to $1.5 \mathrm{MPa}$. The results of the new equipment were similar to the electronic penetrometer, indicating its viability as a tool for assessing the soil physical conditions for plant growth. 
These situations led to the conception of the idea to develop an indigenous design using locally available materials and following certain standard recommended dimensions of the probe. Determining the soil penetration resistance facilitate choosing the suitable tools and safe power. Therefore, this study was mainly carried out to design and evaluate a sensitive penetrometer for measuring soil penetration resistance and consequently determine the towed force needed for tillage and soil preparation tools.

\section{MATERIALS AND METHODS}

A vertical penetrometer was designed in this study to facilitate providing more data easily in the field with no human faults in readings while measuring soil penetration resistance.

Components of the vertical, static penetrometer: The desired characteristics of the construction materials are: local availability, low cost, easy handling during fabrication. The system involves three main components:

Electric motor: An electric motor of $12 \mathrm{v}$ DC was selected to generate sufficient power to rotate a gear connected to a helical screw rod efficiently according to the power needed. The 12v DC motor is small, light and inexpensive, yet powerful enough to be used for carrying out the application. The electric motor characteristics are shown in (Table 1).

Table 1. The electric motor characteristics

\begin{tabular}{|l|c|l|l|}
\hline Item & & Item & \\
\hline Place of Origin: & Guangdong, China & Voltage $(\mathrm{V}):$ & 12 \\
\hline Torque: & $2 \sim 8 \mathrm{~N} . \mathrm{m}$ & diameter: & $59 \mathrm{~mm}$ \\
\hline Speed (RPM): & $10 \sim 300 \mathrm{rpm}$ & efficiency: & $>45 \%$ \\
\hline Output Power: & $30 \sim 80 \mathrm{~W}$ & weight: & $1 \mathrm{~kg}$ \\
\hline gear box direction: & left and right & Life time & base on operator \\
\hline
\end{tabular}

The basic parts of static penetrometer are: electric motor, penetration cone (Fig.1) and load cell (Fig. 2). The main parts of the static penetrometer is shown in Fig. 3. The pipe of ( $\phi 3.81 \mathrm{~cm}$ and $75 \mathrm{~cm}$ long) was made of stainless steel and was welded to a rectangular section pipe of $4.51 \times 3 \mathrm{~cm}$ and $75 \mathrm{~cm}$ long. The load cell was placed inside this rectangular pipe to be protected as this prevents possible damage to the load cell while processing. The data cables of the load cells were transported to the data collection software unit by being passed through the steel pipe moved aside the penetrometer pipes. All rods supported with ball bearings in order to prevent probable friction. A graduated steel scale was welded aside the rectangular pipe to determine the certain depth with readings of soil penetration resistance (PR). 
Cone tip: The design of the cone and the rigid supporting rod illustrated in Fig. 1 follows the ASAE (American Society of Agricultural Engineers, 1992) for a soil cone penetrometer, which is based on the design developed by the United States Army Corps of Engineers WES (Waterways Experiment Station, 1948).

It consists of a hardened stainless steel cone with a $20.5 \mathrm{~mm}$ diameter base mounted on a shaft ( $\phi 16.0 \mathrm{~mm}$ and $75 \mathrm{~cm}$ long). The conical-shaped tip of $30^{\circ}$ was fixed to a $75 \mathrm{~cm}$ rod attached to the load cell. The surface area of the designed conical-shaped tip is $323 \mathrm{~mm}^{2}$.

Helical screw pitch: The steel pipe involved an internal helical screw rod $(\phi 1.6 \mathrm{~cm}$ and $75 \mathrm{~cm}$-long) fixed to a load cell. Helical screw pitch of $2 \mathrm{~mm}$ and displacement were designed according to Parkin 2006. Each 5 screw rotations gives a displacement of $1.0 \mathrm{~cm}$. After laboratory trials, the electric motor was adjusted to rotate $60 \mathrm{rpm}$ by built-in screw gear. It means $12 \mathrm{~cm}$ displacement/min. Accordingly, a constant speed of $0.002 \mathrm{~m} / \mathrm{s}$ was recorded.

Load cell system: The load cell (Fig. 2) is attached to a steel rod to measure soil penetration resistance in $\mathrm{kg} / \mathrm{cm}^{2}$ which converted into MPa units as $1.0 \mathrm{~kg} / \mathrm{cm}^{2}$ approximately $=0.098 \mathrm{MPa}$. To measure the soil resistance, LSM-200 $\mathrm{kg} \mathrm{S}$ type load cell was used. This S-Type load cell (sometimes called a strain gauge) can translate up to $200 \mathrm{~kg}(1962 \mathrm{~N}$ ) of pressure (force) into an electrical signal. Each load cell is able to measure the electrical resistance that changes in response and proportion to the strain (e.g., pressure or force) applied to the form. These load cells have four strain gauges that are hooked up in a Wheatstone bridge formation. Specifications of load cell used are shown in (Table 2).

Analog Digital Converter with accuracy of $0.001 \mathrm{~kg}$ was used for translating the signal produced by the load cell and converting it into a strength value after the digital signal conversion process. Calibration of the load cell was performed via connected indicator, according to the datasheet instructions provided. 


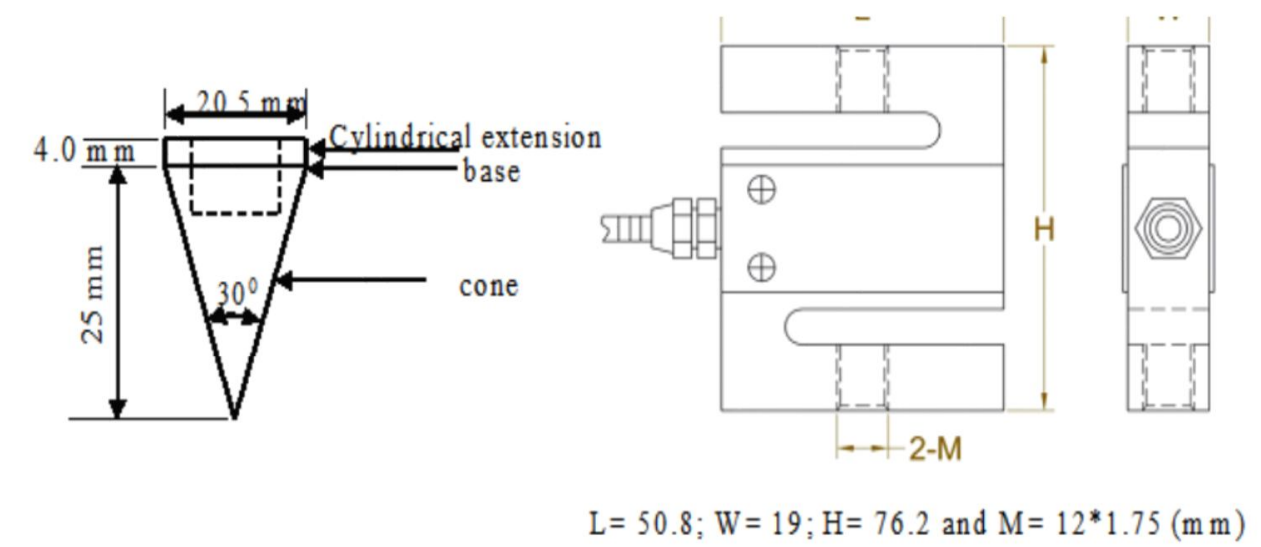

Fig. 2: The used S type load cell

Fig. 1: A conical-shaped tip of $30^{\circ}$

Table 2. Specifications of load cell used

\begin{tabular}{|c|c|c|c|}
\hline Rated Capacity & $200 \mathrm{~kg}$ & Operating Temperature Range & $-20 \ldots+60^{\circ} \mathrm{C}$ \\
\hline Rated Output & $2.0 \pm 10 \% \mathrm{mV} / \mathrm{V}$ & Temperature Shift On Zero & $\pm 0.05 \%$ of R.O./100C \\
\hline Zero Balance & $\pm 2 \%$ of R.O. & Input Resistance & $350 \pm 30 \Omega$ \\
\hline Creep(30min) & $\pm 0.03 \%$ of R.O. & Output Resistance & $350 \pm 5 \Omega$ \\
\hline Ultimate Overload & $200 \%$ of F.S. & Material of Element & Alloy steel \\
\hline Compensated & $-10 \ldots+40 \circ$ & Cable & $\Phi 5 * 1800 \mathrm{~mm}, 4-$ conductor \\
Temperature Range & & & shielded cable \\
\hline
\end{tabular}




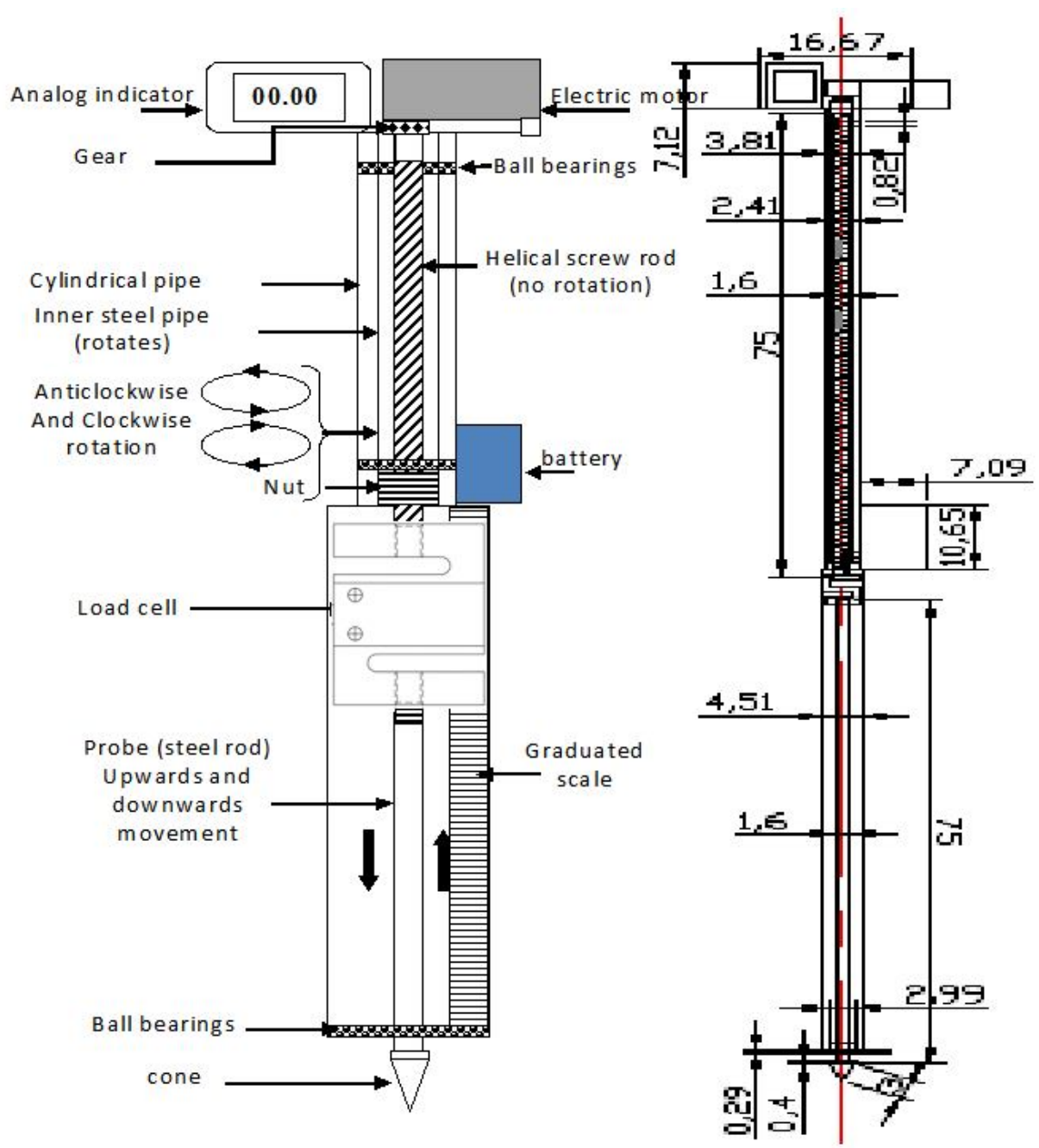

Fig. 3. A schematic diagram and 2D-drawing of penetrometer with (dim. in $\mathrm{cm}$ )

An adjustable bed system was placed at the end of the penetrometer to ensure a well-maintained depth adjustment and proper running of the operation. The total mass of the designed sensitive system including the battery was $8.5 \mathrm{~kg}$.

The mechanism of application: According to Fig. 3, when the motor gear rotates horizontally (clockwise and anticlockwise), it simultaneously drives a nut welded to the end of inner steel pipe of $2.41 \mathrm{~cm}$ which vertically rotates. The internal helical screw only pressed on the load cell at the upper face. Then, the lower face of the load cell connected to a steel rod, probe ended with penetrating cone moves downwards under soil surface. The electrical resistance that changes in response and proportion to the strain which represents the value of soil penetration resistance is transmitted through a cable to the analog indicator. This value is converted by analog screen into digital readings. The penetration depth is measured by graduated scale. It is very important to assure that, both internal helical screw and the steel rod with cone or load cell 
never rotate. Only the motor gear which fixed to the inner steel pipe ended with nut rotates.

Hardpan: According to obtained data in the field, soil depth of 30-45 showed the highest PR. Therefore, this depth was chosen to determine the hardpan in the experimental site.

The system was employed in order to send the force value to the software. For the obtained force data to be converted into penetration resistance (PR), the use of Equation Be lowing was preferred:

$$
\mathrm{PR}(\mathrm{MPa})=\text { force }(\mathrm{N}) / \text { cone area }\left(\mathrm{m}^{2}\right)
$$

Laboratory calibration: The calibration was performed using masses which meet the requirements of BS EN ISO 7500-1, (WWW.LCMSYSTEMS.COM). The new device was calibrated accurately in the lab. Certain masses of 1, 2, 5, 10 and $20 \mathrm{~kg}$ mass were used individually for calibration as follows:

- The device was positioned vertically on a solid surface and turned on.

- Each mass was put individually on upper part of the device and through the analog screen the readings were stored automatically in built-in analog.

- The previous step was repeated with each mass and all readings were stored.

- After repeating the mentioned steps, all obtained readings were compared to the certain weighs.

- All compared readings were the same.

- Between each two steps the system was turned off to prevent confliction between readings.

- Accordingly, adding different weighs i.e. $0.5,1.5$ or $5 \mathrm{~kg}$ or whatever the weighs, on the device analog screen the true weight is read correctly.

- Thus, the device was ready for proceeding experiments.

- Finally, while proceeding trials the device needs to be idled only by pressing tare button on the analog screen.

Comparing calibration: After laboratory calibration of the sensitive penetrometer, it was compared to a dynamic cone penetrometer (DCP) developed by El-Shiekha 1989, to ensure the penetrometer under study. The structure of the DCP consists of two vertical shafts connected to each other at the anvil. The upper shaft has a handle and hammer. The handle is used to provide a standard drop height of $65 \mathrm{~cm}$ for the hammer as well as a way for the operator to easily hold the DCP vertical. The hammer is $8 \mathrm{~kg}$ and provides a constant impact force. The lower shaft has an anvil at the top and a pointed cone on the bottom.

The anvil stops the hammer from falling any further then the standard drop height. When the hammer is dropped and hits the anvil, the cone is driven into the ground. 
The DCP tip (Fig. 4) can either be a replaceable point or a disposable cone. Fig. 4 shows the typical configuration of dynamic cone penetrometer.

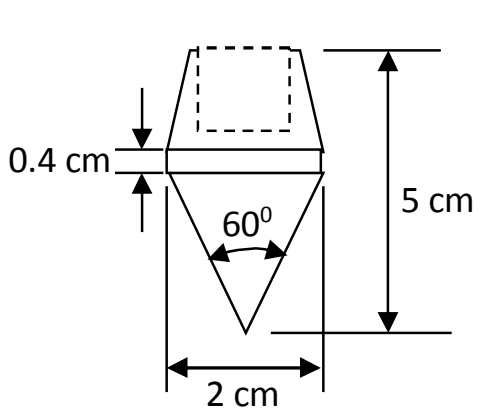

Cone tip

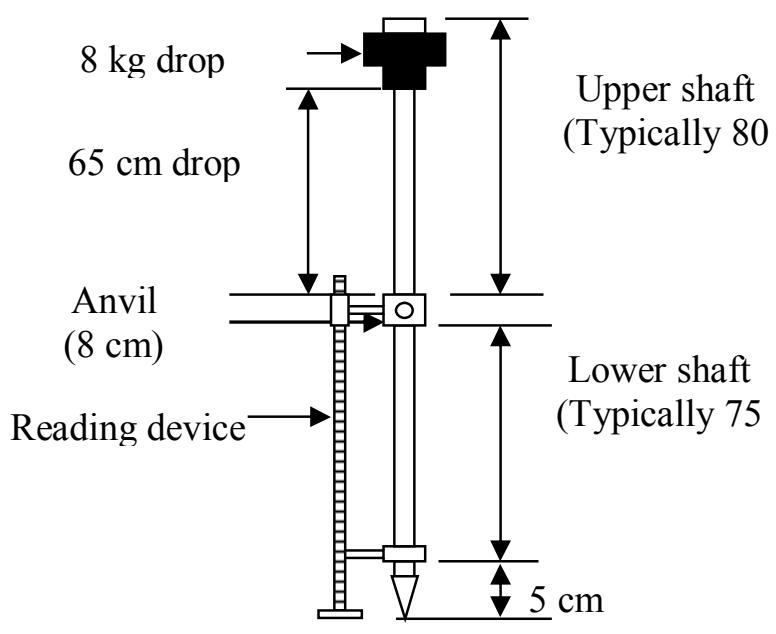

Fig. 4. Structure of Dynamic Cone Penetrometer

Three types of soils i.e. clayey, sandy-clay and sandy were chosen in two conditions of each i.e. un-compacted and compacted. In different types of the experimented soils and according to soils bulk density (BD) the readings of soil penetration resistance (PR) were tabulated.

Results of The Dynamic Cone Penetrometer (DCP) in general are given as incremental values defined as follows:

$$
\begin{gathered}
D C P I_{1}=\frac{\Delta D p_{1}}{\Delta B C_{1}}, \quad D C P I_{2}=\frac{\Delta D p_{2}}{\Delta B C_{2}}, \quad D C P I_{3}=\frac{\Delta D p_{3}}{\Delta B C_{3}} \\
D C P I=\frac{D C P I_{1}+D C P I_{2}+D C P I_{3}}{3}
\end{gathered}
$$

Where, DCPI = DCP penetration index in units of length divided by blow count; $\triangle \mathrm{Dp}=$ Penetration depth; $\mathrm{BC}=$ blow counts corresponding to penetration depth $\triangle \mathrm{Dp}$.

As a result, values of the penetration index (PI) represent DCP characteristics at certain depths.

Experimental Site: In two-way a randomized complete block design, with four replicates, the trials were carried out in the field using the sensitive penetrometer system in El-Serw Agricultural Research Station, Damietta Governorate. The soil type characteristics is illustrated in (Table 3). Soil texture is clayey. Content of organic 
matter was $1.3 \%$. Soil bulk density, water content and soil resistance values were determined at a depth between 30 and $45 \mathrm{~cm}$ according to hardpan layer.

Table 3. Soil characteristics according to mechanical analysis

\begin{tabular}{|c|c|c|c|c|}
\hline Depth, $\mathrm{cm}$ & Clay, $\%$ & Silt, $\%$ & Fine sand, $\%$ & Coarse sand, \% \\
\hline $0-15$ & 64.16 & 21.80 & 12.49 & 1.55 \\
\hline $15-30$ & 67.02 & 22.05 & 9.08 & 1.85 \\
\hline $30-45$ & 59.76 & 24.15 & 13.92 & 2.17 \\
\hline $45-60$ & 61.34 & 22.10 & 14.33 & 2.23 \\
\hline
\end{tabular}

Data Collection: The experimental field is one feddan in area. During the experiments, no variations were seen in the motor speed as the electric motor was chosen to keep the speed at a constant value to avoid any negative effect of speed changes on the soil penetration resistance. The experiments were carried out in a field shortly after a week from rice harvesting and measurement values of $0-15,15-30,30$ 45 and $45-60 \mathrm{~cm}$ below soil surface and $15 \mathrm{~m}$ linear intervals were obtained. Much research indicates that the depth of the hardpan is mostly between 30 and $45 \mathrm{~cm}$. The obtained data was recorded and tabulated.

After completion of the penetrometer probe measurements, core samples were taken in $5 \mathrm{~cm}$ increments from the soil surface to the $60 \mathrm{~cm}$ depth using aluminum rings ( $5 \mathrm{~cm}$ diam. and $5 \mathrm{~cm}$ height) for subsequent soil bulk density and gravimetric water content determinations in the laboratory. Samples for the two compared penetrometers were taken in the same time and place in the field.

Test factors and measurements: Different soil depths, soil moisture contents (MC) and soil bulk densities (BD) were studied after two days, one week and two weeks from harvesting in the open field at constant penetration speed of $0.002 \mathrm{~m} / \mathrm{s}$ in uncompacted soil and accordingly the soil penetration resistance (PR) was measured and tabulated. Test factors are shown in (Table 4).

Table 4. Test factors

\begin{tabular}{|c|l|c|c|c|c|c|}
\hline \multirow{2}{*}{$\begin{array}{c}\text { Soil depth, } \\
\mathrm{cm}\end{array}$} & \multicolumn{3}{|c|}{ Un-compacted soil } & \multicolumn{2}{c|}{ Compacted soil } \\
\cline { 3 - 7 } & & $\begin{array}{c}\text { After two } \\
\text { days }\end{array}$ & $\begin{array}{c}\text { After one } \\
\text { week }\end{array}$ & $\begin{array}{c}\text { After two } \\
\text { weeks }\end{array}$ & $\begin{array}{c}\text { After one } \\
\text { week }\end{array}$ & $\begin{array}{c}\text { After two } \\
\text { weeks }\end{array}$ \\
\hline \multirow{2}{*}{$0-15$} & $\mathrm{MC}, \%$ & 59.22 & 32.65 & 22.46 & 32.65 & 22.46 \\
\cline { 2 - 7 } & $\mathrm{BD}, \mathrm{g} / \mathrm{cm}^{3}$ & 1.09 & 1.14 & 1.23 & 1.35 & 1.32 \\
\hline \multirow{2}{*}{$15-30$} & $\mathrm{MC}, \%$ & 58.12 & 32.16 & 18.23 & 32.16 & 18.23 \\
\cline { 2 - 7 } & $\mathrm{BD}, \mathrm{g} / \mathrm{cm}^{3}$ & 1.125 & 1.16 & 1.27 & 1.46 & 1.41 \\
\hline \multirow{2}{*}{$30-45$} & $\mathrm{MC}, \%$ & 57.5 & 31.12 & 16.11 & 31.21 & 16.11 \\
\cline { 2 - 7 } & $\mathrm{BD}, \mathrm{g} / \mathrm{cm}^{3}$ & 1.13 & 1.19 & 1.29 & 1.59 & 1.53 \\
\hline \multirow{2}{*}{$45-60$} & $\mathrm{MC}, \%$ & 57 & 30.14 & 15.43 & 30.14 & 15.43 \\
\cline { 2 - 7 } & $\mathrm{BD}, \mathrm{g} / \mathrm{cm}^{3}$ & 1.132 & 1.21 & 1.33 & 1.71 & 1.62 \\
\hline
\end{tabular}

The same measurements were carried out in compacted soil after one week and after two weeks by passing a tractor with mass of 4 tons in one pass, two passes, three passes and four passes. 
Also, a comparison between the sensitive penetrometer and the dynamic penetrometer was carried out in the field.

Data analysis: Data were analyzed using a statistical computer program (CoStat) estimating ANOVA and determining regression analysis with the significance level at 0.05 .

\section{RESULTS AND DISCUSSION}

Soil penetration resistance in un-compacted soil: Relationships between soil penetration resistance (PR), soil moisture content (MC) and soil bulk density (BD) after two days from irrigation in un-compacted soil are illustrated in Figs. (5 and 6).

There is an inversely proportion in the relationship between soil penetration resistance and soil moisture content. Soil penetration resistance increased with a decrease of soil moisture content across the whole measured water content range.

Measured minimum and maximum PR values were 0.306 and $0.445 \mathrm{MPa}$, after $24 \mathrm{~h}$. (two days) from irrigation under 59.22 and $57.5 \%$ in depths of (0-15) and (30-45 cm), respectively. These results were under soil BD of 1.09 and $1.13 \mathrm{gm} / \mathrm{cm}^{3}$, respectively. Soil depths of $15-30$ and $45-60 \mathrm{~cm}$ showed 0.319 and $0.378 \mathrm{MPa}$ respectively under the same condition of both $M C$ and BD. Soil depth of 30-45 cm showed the highest value of $P R$ with highest value of $B D$. These small values of $P R$ may be because of high moisture content and less BD in un-compacted soil. These results are in agree with Mehmet et al. (2010). ANOVA analysis at level 0.05 showed a significant effect for both $\mathrm{MC}$ and consequently BD on PR under different conditions, (Table 5).

Relationships between PR, MC, and BD at different depths after a week from irrigation were best described by additive models of the form presented in Figs ( 7 and 8). The minimum and maximum values of PR were 0.675 and $0.728 \mathrm{MPa}$ under $\mathrm{BD}$ of 1.14 and $1.19 \mathrm{~g} / \mathrm{cm}^{3}$, respectively and also under MC of 32.65 and $31.12 \%$. Other MC and $B D$ values showed similar trends under the same conditions. The highest value of PR of $0.728 \mathrm{MPa}$ was obtained at soil depth of $30-45 \mathrm{~cm}$. ANOVA analysis at level 0.05 showed a significant effect for both MC and BD on PR under different conditions, (Table 6).

On the other hand, the PR values under different MC and BD after two weeks from irrigation were described on Figs. (9 and 10). Increasing BD resulted in increasing PR. While increasing MC caused low values of PR and vice versa. The minimum and maximum values of PR after two weeks from irrigation of 0.709 and $0.798 \mathrm{MPa}$ were obtained at soil depth of $30-45 \mathrm{~cm}$ under MC of 22.46 and $16.11 \%$, respectively. 


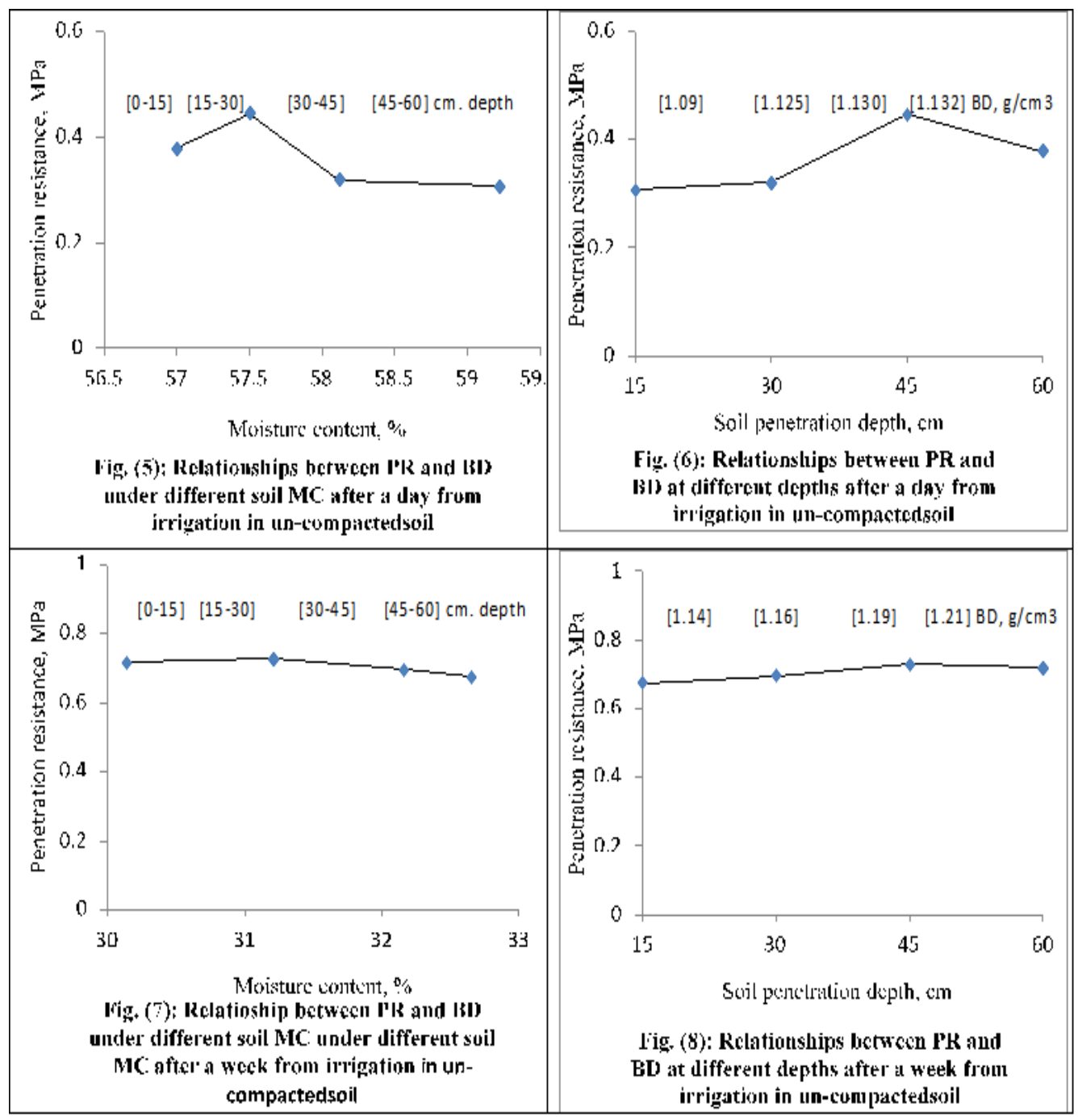

Table 5. ANOVA analysis for studied parameters and the interaction between them at significance level of 0.05 after two days from irrigation in un-compacted soil

$\begin{array}{lcllllll}\text { Source } & \text { df } & \text { Type III } & \text { SS } & \text { MS } & \text { F } & \text { P } \\ \text { Blocks } & 2 & 1.25 \mathrm{e}-5 & 6.25 \mathrm{e}-6 & & 1.8 & .2441 & \mathrm{~ns} \\ \text { BD } & 3 & 0.036642667 & 0.0122 & 3517.696 & .0000 & * * * \\ \text { Error } & 6 & 2.083333 \mathrm{e}-5 & 3.4722 \mathrm{e}-6<- & & \\ \text { Total } & 11 & 0.036676 & \mathrm{R}^{2}=0.999 & & & \end{array}$

Table 6. ANOVA analysis for studied parameters and the interaction between them at significance level of 0.05 after a week from irrigation in un-compacted soil

$\begin{array}{lllllll}\text { Source } & \mathrm{df} & \text { Type III } & \mathrm{SS} & \mathrm{MS} & \mathrm{F} & \mathrm{P} \\ \text { Blocks } & 2 & 1.05 \mathrm{e}-5 & 5.25 \mathrm{e}-6 & 1.173913 & .3713 & \mathrm{~ns} \\ \text { BD } & 3 & 0.158530917 & 0.0528436 & 11815.969 & .0000 & * * * \\ \text { Error } & 6 & 2.683333 \mathrm{e}-5 & 4.4722 \mathrm{e}-6<- & & & \\ \text { Total } & 11 & 0.15856825 & \mathrm{R}^{2}=0.99 & & & \end{array}$




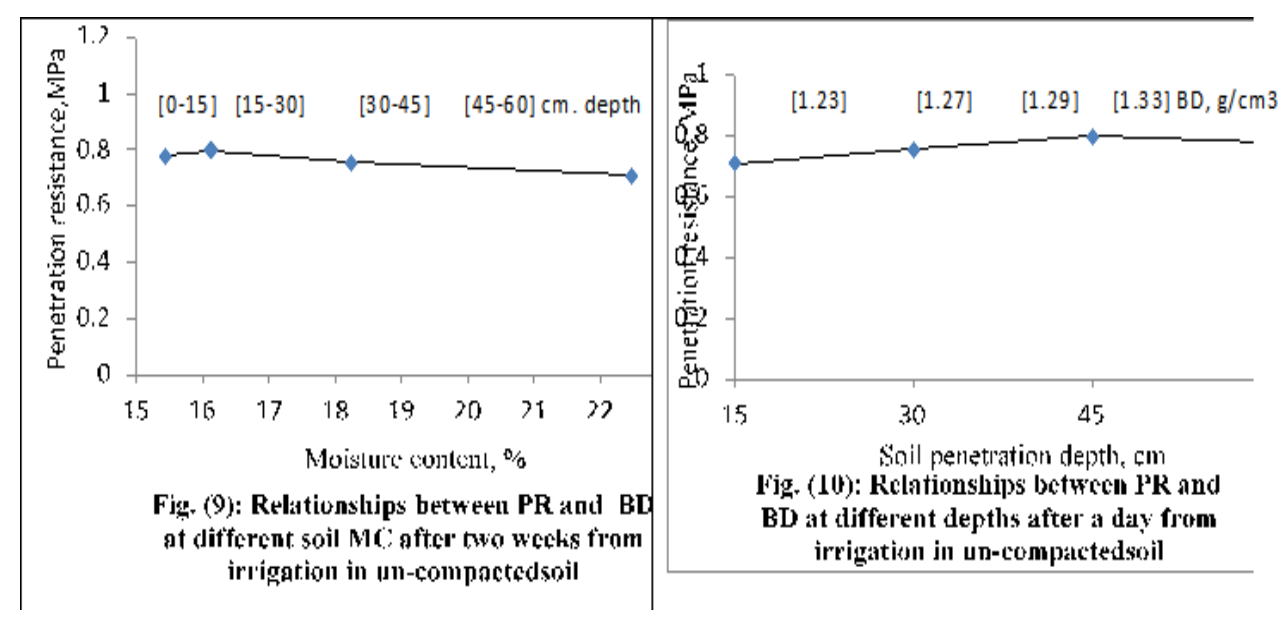

All these results were under BD of 1.23 and $1.29 \mathrm{~g} / \mathrm{cm}^{3}$. That means a direct relationship between PR and $B D$ and inverse relationship with $M C$. The other soil depths showed similar behavior on the figure. The different values in PR after one week and two weeks may be due to the decrease in MC which accordingly increases the soil BD. However the similarity between the obtained data in un-compacted soil, the replicates showed no significant effect and this means the high sensitivity of the penetrometer under study. ANOVA analysis at level 0.05 showed a significant effect for both MC and accordingly BD on PR under different conditions, (Table 7).

Table 7: ANOVA analysis for studied parameters and the interaction between them at significance level of 0.05 after two weeks from irrigation in un-compacted soil

$\begin{array}{lcccccr}\text { Source } & \mathrm{df} & \text { Type III } & \text { SS } & \text { MS } & \mathrm{F} & \mathrm{P} \\ \text { Blocks } & 2 & 7.216667 \mathrm{e}-5 & 3.6083 \mathrm{e}-5 & 86.6 & .0000 & * * * \\ \text { BD } & 3 & 0.012847 & 0.0042823 & 10277.6 & .0000 & * * * \\ \text { Error } & 6 & 2.5 \mathrm{e}-6 & 4.1667 \mathrm{e}-7<- & & & \\ \text { Total } & 11 & 0.012921667 & \mathrm{R}^{2}=0.99 & & & \end{array}$

The different values of soil particle size distribution, generate distinct structures and alter the soil physical behavior under dynamic force of the soil management, affecting the penetrometer resistance as well as soil water conditions. Considering the strong dependence of penetration resistance on soil water content within a soil profile across the field, it would be beneficial of both soil water content and soil resistance could be measured simultaneously at the same location and depth.

Soil penetration resistance in compacted soil : The relationships between MC, $\mathrm{BD}$ and PR after a week from irrigation in compacted soil are depicted in Figs. (11 and 12). According to the increase in $B D$ according to one pass to four passes, the PR increased as a result. Increasing BD from 1.35 to $1.71 \mathrm{~g} / \mathrm{cm}^{3}$ resulted in increasing PR from 1.162 to $2.365 \mathrm{MPa}$ under $30.14 \%$ of soil MC and soil depth of $45-60 \mathrm{~cm}$. The 
maximum value of $\mathrm{PR}$ of $2.371 \mathrm{MPa}$ was under soil depth of $30-45 \mathrm{~cm}$ with $\mathrm{BD}$ of 1.59 $\mathrm{g} / \mathrm{cm}^{3}$ (four passes) was obtained at $31.21 \%$ of soil MC while the minimum values of PR of 0.891 was under $32.65 \%$ and $1.35 \mathrm{~g} / \mathrm{cm}^{3}$ (one pass) for both $\mathrm{MC}$ and $\mathrm{BD}$, respectively and soil depth of $0-15 \mathrm{~cm}$. For the compacted soil, PR increased marginally with increasing BD (more passes by the tractor), while soil MC had a relatively greater impact on PR than $\mathrm{BD}$. Two and three passes by the tractor showed similar trends on the mentioned figures. Though PR was more sensitive to BD at high MC, PR was less sensitive to BD than that typically reported for un-compacted soils due, in part, to the sampling approach used. The inclusion of sensitive PR data depicted in Figs. (13 and 14). has resulted in PR being biased downward, particularly at high $\mathrm{BD}$ and low soil moisture.

ANOVA analysis showed a significant effect for both MC and BD on PR under different conditions, (Table 8).

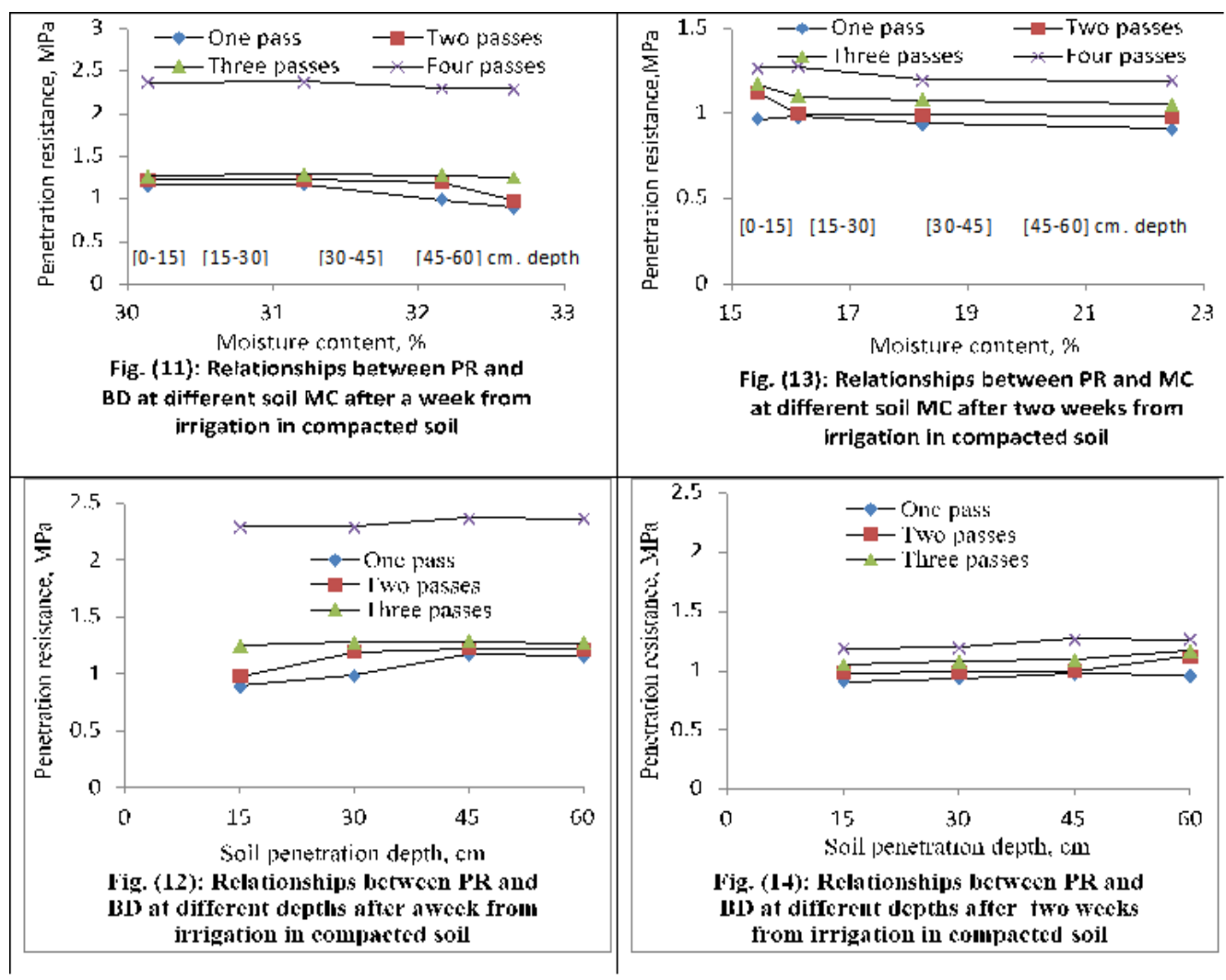


The relationships between MC, BD (according to tractor passes) and PR after two weeks from irrigation in compacted soil are depicted in Figs. (13 and 14). It could be concluded that increasing number of tractor passes on the soil resulted in more soil penetration resistance under all conditions. According to the increase in $B D$, the PR increased. Increasing BD in depth of $0-15 \mathrm{~cm}$ from $1.32 \mathrm{~g} / \mathrm{cm}^{3}$ under $32.65 \% \mathrm{MC}$ to $1.62 \mathrm{~g} / \mathrm{cm}^{3}$ resulted in increasing PR from 1.191 to $1.266 \mathrm{MPa}$ under $15.43 \%$ of soil MC and soil depth of $45-60 \mathrm{~cm}$. Soil depth of $30-45 \mathrm{~cm}$ shoed PR of $1.273 \mathrm{MPa}$ under $\mathrm{BD}$ of $1.53 \mathrm{~g} / \mathrm{cm}^{3}$ (four passes).

Table 8. ANOVA analysis for studied parameters and the interaction between them at significance level of 0.05 after a week from irrigation in compacted soil

\begin{tabular}{lcccccc} 
Source & df & Type III SS & \multicolumn{2}{c}{ MS } & P \\
Blocks & 2 & 0.041839625 & 0.0209198 & 1.003812 & .4207 & ns \\
MC & 3 & 9.776490167 & 3.2588301 & 156.37104 & .0000 & $* * *$ \\
Main Plot Error & 6 & 0.125042208 & $0.0208404<-$ & & & \\
Passes & 3 & 0.749548333 & 0.2498494 & 11.992226 & .0001 & $* * *$ \\
Passes * MC & 9 & 0.661910833 & 0.0735456 & 3.5300299 & .0065 & $* *$ \\
Error & 24 & 0.500022833 & $0.0208343<-$ & & & \\
Total & 47 & 11.854854 & $\mathbf{R}^{2}=\mathbf{0 . 9 5}$ & & &
\end{tabular}

The maximum value of PR of $1.273 \mathrm{MPa}$ under the same condition of bulk density $1.53 \mathrm{~g} / \mathrm{cm}^{3}$ was obtained at $16.11 \%$ of soil MC at soil depth of $30-45 \mathrm{~cm}$, while the minimum values of PR of $0.913 \mathrm{MPa}$ was under soil depth of $0-15 \mathrm{~cm}$ with $22.46 \%$ and $1.32 \mathrm{~g} / \mathrm{cm}^{3}$ for both MC and BD, respectively. ANOVA analysis showed a significant effect for MC and BD on PR under different conditions, (Table 9).

For the compacted soil, the rate of change in PR with soil moisture was greater at higher $\mathrm{BD}$, and the rate of change in PR with $\mathrm{BD}$ was greater at lower soil moisture. Interactions between soil penetration resistance, bulk density, and soil moisture were stronger in the compacted soil than the un-compacted soil, due in part to heterogeneity of compacted soil.

The penetration resistance range of most interest to soil management is zero to $5 \mathrm{MPa}$. Within this range, root growth will be severely restricted or inhibited, and soil shear strength will provide sufficient resistance to compaction from commonlyused dynamic equipment. It follows, therefore, that if responses in field soil penetration resistance to changes in bulk density and soil moisture are to be usefully predicted, narrow confidence limits of prediction (possibly less than $\pm 0.25 \mathrm{MPa}$ ) will be required. These results are cope with results obtained by João et al. (2010). 
Table 9: ANOVA analysis for studied parameters and the interaction between them at significance level of 0.05 after two weeks from irrigation in compacted soil

$\begin{array}{lcccccc}\text { Source } & \text { df } & \text { Type III } & \text { SS } & \text { MS } & \text { F } & \text { P } \\ \text { Blocks } & 2 & 2.116667 \mathrm{e}-5 & 1.0583 \mathrm{e}-5 & 127 & .0000 & * * * \\ \text { MC } & 3 & 0.06539025 & 0.0217968 & 261561 & .0000 & * * * \\ \text { Main Plot Error } & 6 & 5 \mathrm{e}-78.3333 \mathrm{e}-8<- & & & & \\ \text { Passes } & 3 & 0.524776417 & 0.1749255 & 839642.27 & .0000 & * * * \\ \text { Passes * MC } & 9 & 0.022104583 & 0.0024561 & 11789.111 & .0000 & * * * \\ \text { Error } & 24 & 5 \mathrm{e}-6 & 2.0833 \mathrm{e}-7<- & & & \\ \text { Total } & 47 & 0.612297917 & \mathrm{R}^{2}=0.99 & & & \end{array}$

Comparing calibration data : Table 10 shows a laboratory comparison experiment between the obtained results of the two types of dynamic and static penetrometers according to measuring the penetration resistance (PR). Data was compared according to SE and SD with confidence level (95\%) under the three types of soil textures clayey, sandy-clay and sandy. Each type of soil was in two cases, uncompacted and compacted case. Data obtained showed approximately similar results with SE or SD for the two penetrometers under different types of soil. The differences were obvious especially in the two cases of clayey soil of 0.353 and $2.371 \mathrm{MPa} ; 0.351$ and 2.372 MPa for the dynamic and static penetrometer and for un-compacted and compacted case, respectively at soil depth of $30-45 \mathrm{~cm}$. The differences could be neglected which means that the new sensitive penetrometer after calibration gave approximately similar results of PR given by the dynamic one but more easily and accurately.

Table 10: A comparison between dynamic and static penetrometers according to mean PR and data analysis.

\begin{tabular}{|c|c|c|c|c|c|c|c|}
\hline $\begin{array}{c}\text { Soil } \\
\text { type }\end{array}$ & Soil case & $\begin{array}{c}\text { Dynamic } \\
\text { penetrometer }\end{array}$ & $\begin{array}{c}\text { Static } \\
\text { penetrometer }\end{array}$ & \begin{tabular}{c} 
Standard \\
Error \\
\cline { 3 - 8 }
\end{tabular} & $\begin{array}{c}\text { Standard } \\
\text { Deviation } \\
(\mathrm{SR})\end{array}$ & Range & $\begin{array}{c}\text { Confidence } \\
\text { Level } \\
(95.0 \%)\end{array}$ \\
\hline \multirow{2}{*}{ Clayey } & Un-comp. & 0.353 & 0.351 & 0.001 & 0.0014 & 0.002 & 0.0127 \\
\cline { 2 - 8 } & Compacted & 2.371 & 2.372 & 0.0005 & 0.0007 & 0.001 & 0.0063 \\
\hline
\end{tabular}

Since PR is one of the soil physical properties directly related to plant growth and development, it is worth remembering the importance of the proposed equipment due to its low cost and easy transport and operation, which enables farmers to diagnose a series of problems caused by soil compaction more easily. Furthermore, the new penetrometer allows measurements to a depth of $75 \mathrm{~cm}$, offering a comprehensive and precise diagnostic of the soil compaction state, which is particularly important in cases of a deep root system, for example, of sugar cane and in fruit orchards. 


\section{SUMMARY AND CONCLUSION}

This study was mainly carried out to determine the towed force needed for tillage tools according to measuring soil penetration resistance. In this paper a new design for instantly measuring the soil resistance has been discussed. The starting point of this research is that a vertical static penetrometer offers more data on the field, so the high volume of data at hand provides more opportunity to make active, effective and productive evaluations about the field type to determine tillage tools size and power needed. From the study, it can be concluded that one of the most crucial factors during the data collection is "speed progress". During the experimental study, speed progress is kept constant while using the new static penetrometer.

1. The results of the sensitive static penetrometer to determine soil penetration resistance under different depths were similar to the dynamic penetrometer, already widely used in agronomic evaluations.

2. In un-compacted soil, range of soil penetration resistance values were 0.306 and $0.991 \mathrm{MPa}$ whereas, in compacted soil, the range of penetration resistance were 0.891 and $2.371 \mathrm{MPa}$, respectively at $30-45 \mathrm{~cm}$ soil depth under different conditions of moisture content and bulk density.

3. The easy use, reduced maintenance and ease of transport favor the use of the proposed penetrometer by farmers and soil scientists.

4. Moisture content and bulk density should be measured instantly while measuring soil penetration resistance as well.

\section{REFERENCES}

1. Adamchuk, V. I.; A. V. Skotnikov; Speichinger, J. D. and M. F. Kocher 2003. Instrumentation System for Variable Depth Tillage. In Proceedings of ASAE Annual International Meeting, Las Vegas, NV, USA, Paper No.03-1078.

2. American Society of Agricultural Engineers. (ASAE), 1999. Procedures for using and reporting data obtained with the soil cone penetrometer. St. Joseph, 1999. p.964- 966. (ASAE standard: ASAE EP542).

3. American Society of Agricultural Engineers, ASAE, 1992. American Society of Agricultural Engineers Standards. 39th edition. ASAE, St. Joseph, MI.

4. Ani O. and C. C. Mbajiorgu 2008. Development of a digital cone penetrometer. Journal of Agricultural Engineering and Technology (JAET), V. 16 (1), p: 84-92.

5. Beutler, A. N.; N. L. N. Silva; Curi, N.; M. M. Ferreira; Cruz, J. N. and I. A. Pereira F. 2001. Resistência a penetração e permeabilidade de Latossolo Vermel hodistróficotípico sob sistemas de manejonaregião dos cerrados. R. Bras. Ci. Solo, 25:16-177

6. Campbell, D. J.; M. F. O'Sullivan 1991. The cone penetrometer in relation to trafficability, compaction and tillage. P.399-430 in Smith, K. A; Mullins, C.E. (Ed.) "Soil Analysis: Physical Methods". Marcel Dekker Inc., New York. 
7. Carrara, M.; A. Castrignanò; Comparetti, A.; P. Febov and S. Orlando 2007. Mapping of penetrometer resistance in relation to tractor traffic using multivariate geostatistics. Geoderma, 142:294-307.

8. Dexter, A. R.; E. A. Czyz and O.P. Gate 2007. A method for prediction of soil penetration resistance. Soil Till. Res., 93:412-419.

9. El-Sheikha, M. A. 1989. A quick and effective method to prepare seedbed for Egyptian farms. Misr J. Agric Eng. 6 (3): 213-223.

10. Jeffrey E. H. and Tim L. J. 2002. A dynamic cone penetrometer for measuring soil penetration resistance. Soil science society of America Journal. Vol. 66 (4): 1320-1324.

11. João C. M.; Getulio C. F. and Álvaro L. M. 2010. Portable Penetrometer for Agricultural Soil: Sensitivity Test to Identify Critical Compaction Depth. R. Bras. Ci. Solo, 34:1823-1829.

12. Mehmet T.; Ilker U. M. C.; Huseyin K. C. and Davut K. 2010. Design of a Horizontal Penetrometer for Measuring On-the-Go Soil Resistance. Sensors, 10: 9337-9348.

13. Parkin A. I. 2008. Alternative Forms for Displacement Screws and Their Pitches. Advances in Robot Kinematics: Analysis and Design, 193-202.

14. Pedrotti, A.; E. A. Pauletto; Crestana, S.; M. M. Ferreira; Dias Juior, M. S.; A. S. Gomes and A. L. Turatti 2001. Resistênciamecânica à penetração de um Planossolosubmetido a diferentessistemas de cultivo. R. Bras. Ci. Solo, 25:521529.

15. Ralisch, R.; T. M. Miranda; Okumura, R.S.; G. M. C. Barbosa; Guimaraes, M. F.; E. Scopel and L.C. Balbino 2008. Resistência à penetração de um LatossoloVermelhoAmarelo do Cerrado sob diferentessistemas de manejo. R. Bras. Eng. Agr. Amb., 12:381-384.

16. Raper, R. L. 2005. Agricultural traffic impacts on soil. J. Terramech., 42: 259-280.

17. Rooney, D. J. and B. A. Lowery 2000. Profile cone penetrometer for mapping soil horizons. Soil Sci. Soc. Am. J., 64:2136- 2139

18. Stolf, R. 1991. Teoria e teste experimental de fórmulas de transformação dos dados de penetrômetro de impactoemresistência do solo. R. Bras. Ci. Solo, 15:229-235

19. Tekin, E.; B. Kul and R. Okursoy 2008. Sensing and 3D mapping of soil compaction. Sensors 2008, 8, 3447-3459.

20. Veiga, M.; R. Horn; D. J. Reinert and M. J. Reichert 2009. Soil compressibility and penetrability of an Oxisol from Southern Brazil, as affected by long-term tillage systems. Soil Till. Res., 92:104-113.

21. Waterways Experiment Station. 1948. Trafficability of soils-Development of testing instruments. U.S. Army Corps of Engineers WES, Vicksburg, MS.

22. WWW.Icmsystems.com/resources/Calibration1.html 


\title{
جهاز اختراق حساس لقياس مقاومة التربة
}

\author{
يوسف يوسف رمضان رمضان \\ معهذ بحوث الهندسة الزراعية - مركز البحوث الزراعية - الجبزة - دصر
}

يعتبر تحديد خصائص الأرض الطبيعية من أهم المعلومات الضرورية للمشتغلين بالإنتاج الزر اعي حيث يتقرر بها أنو اع المحاصيل المناسبة وكثافتها ودورتها الزر اعية وكمية المياه اللازمة ونوع وحجم المعدات الزراعية المستخدمة فى إعداد الأرض وزر اعتها وخدمنها وكذلك حجم آلات

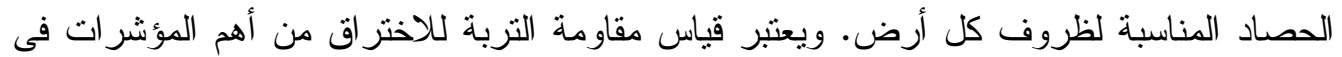

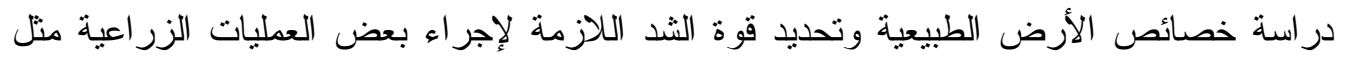
الحرث ، ودر اسة عمق الطبقة الصماء أسفل سطح التربة لتحديد القدرة اللازمة لتكسيرها بتحديد نوع الجرار ومحراث تحت التزبة الو اجب استخدامهما ، وذللك لمنع إهدار الطاقة في غير فائدة.

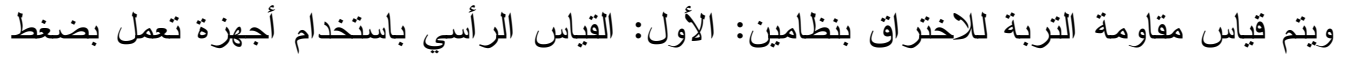

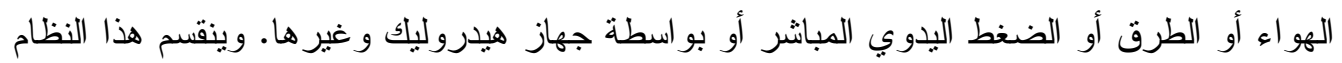

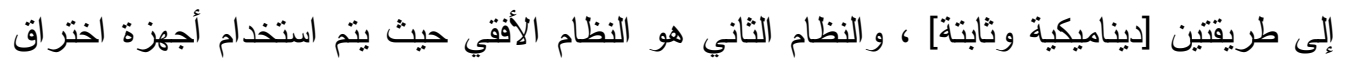

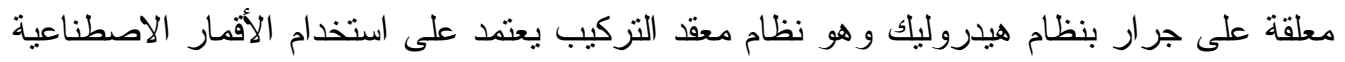

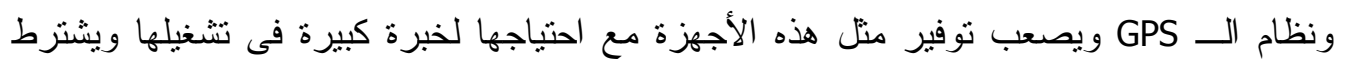

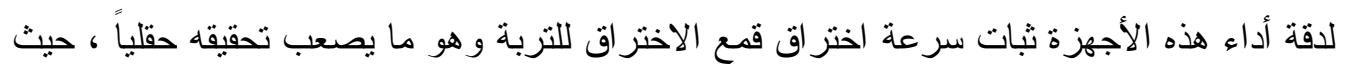

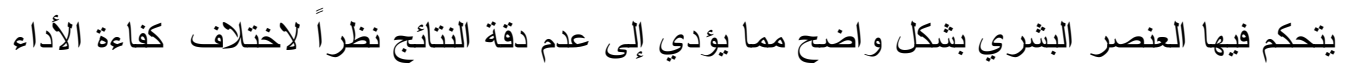

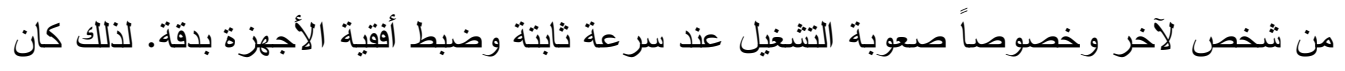
الهدف من الدراسة هو تصميم جهاز اختراق حساس يعمل بنظام القياس الر أسي الثابت ، لا لا يعتمد

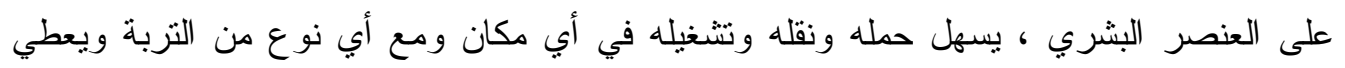
قر اءات مباشرة يمكن الاعتماد عليها فى تحديد خصائص الأرض الطبيعية بدقة. يتكون الجهاز من load cell متصلة من أعلى بفتيل يدار بو اسطة موتور كهربي مركب علئ عليه تزس يدور بسرعة . 7 لفة/دقيقة ومتصلة من أسفل بقضيب من الحديد ينتهي بقمع اختر اق تم اعتماد

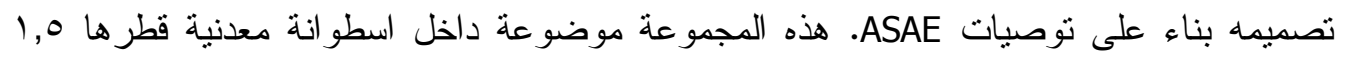

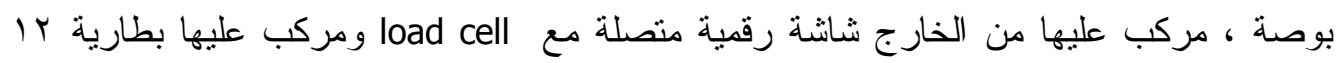

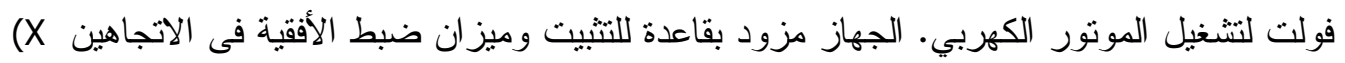

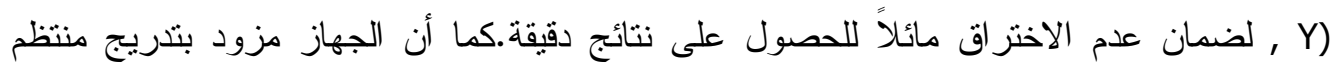

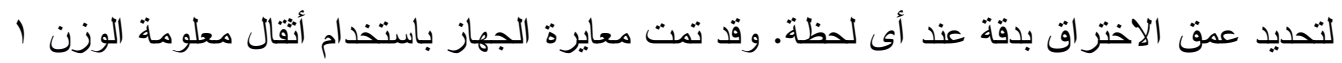

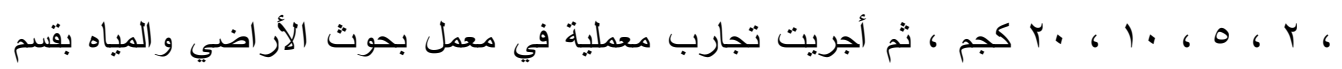

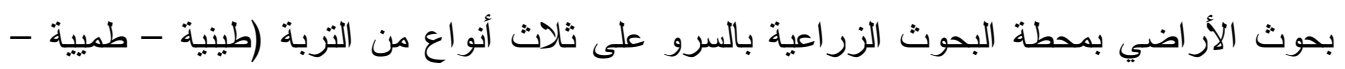


رملية) في حالتين لكل نوع من التزبة (مضغوطة وغير مضغوطة) مع اختبار قراءات الجهاز مع جهاز آخر يعمل بالنظام الديناميكي (الطرق) مع تسجيل بيانات القر اءة كل مرة. ثم أجريت تجربة حقلية في تربة طينية فى المزرعة البحثية لمحطة البحوث الزر اعية بالسرو - محافظة دمياط ، بعد الحصاد وإخلاء الأرض من المحصول السابق (الأرز) على فئل أعماق ( • ، 0

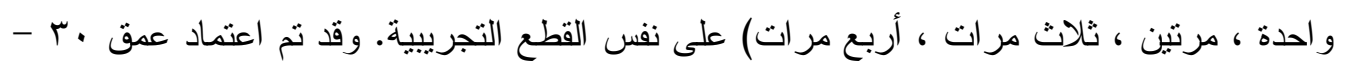

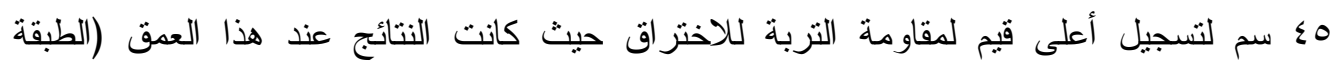
الصماء) أعلى ما يمكن وهو ما يتفق مع الدراسات المرجعية ، تم أخذ قياسات الكثافة الظاهرية

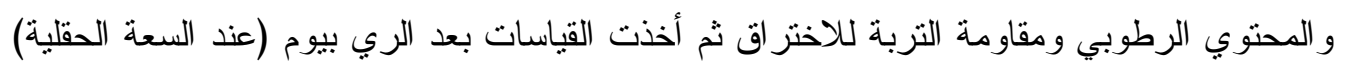

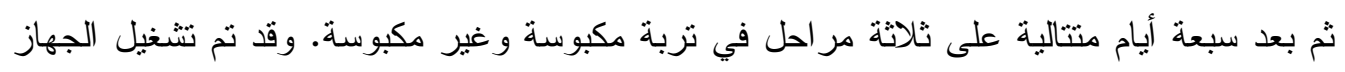

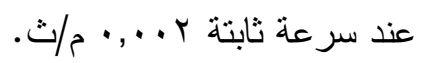

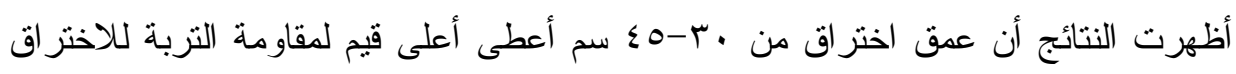

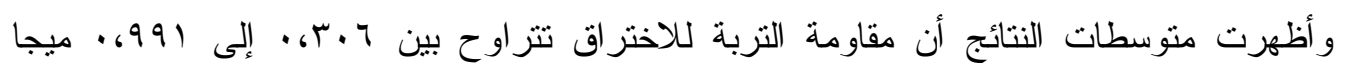

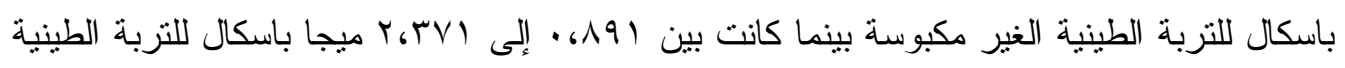

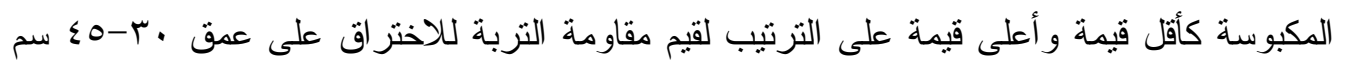

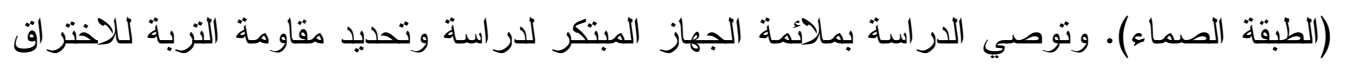

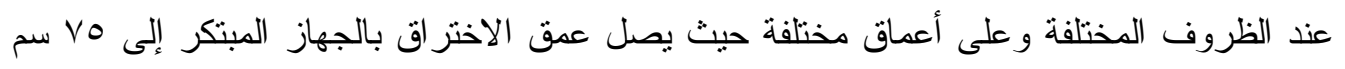

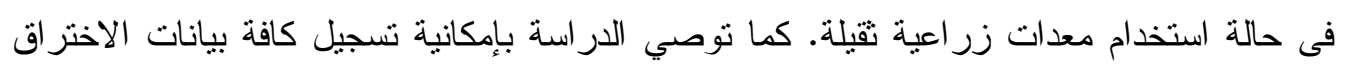
إلكترونياً بالنسبة لعمق وزمن الاختراق مع نزويده بنظام رسم خريطة لبيانات الاختر اق. 